\title{
Risk of wheezing and asthma exacerbation in children treated with paracetamol versus ibuprofen: a systematic review and meta- analysis of randomised controlled trials
}

\author{
Mohamed Sherbash', Luis Furuya-Kanamori ${ }^{2}$, Joanne Daghfal Nader ${ }^{1}$ and Lukman Thalib ${ }^{3^{*}}$ (D
}

\begin{abstract}
Background: Paracetamol and ibuprofen are the most commonly used medications for fever and pain management in children. While the efficacy appears similar with both drugs, there are contradictory findings related to adverse events. In particular, incidence of wheezing and asthma among children taking paracetamol compared to ibuprofen, remain unsettled.

Methods: We conducted a meta-analysis of randomized controlled trials (RCTs) that compared wheezing and asthma exacerbations in children taking paracetamol versus ibuprofen. A comprehensive search was conducted in five databases. RCTs reporting on cases of wheezing or asthma exacerbations in infants or children after the administration of paracetamol or ibuprofen were included. The pooled effect size was estimated using the Peto's odds ratio.

Results: Five RCTs with 85,095 children were included in the analysis. The pooled estimate $(\mathrm{OR} 1.05 ; 95 \% \mathrm{Cl} 0.76-$ 1.46) revealed no difference in the odds of developing asthma or presenting an exacerbation of asthma in children who received paracetamol compared to ibuprofen. When the analysis was restricted to RCTs that examined the incidence of asthma exacerbation or wheezing, the pooled estimate remained similar (OR $1.01 ; 95 \% \mathrm{Cl} 0.63-1.64)$. Additional bias adjusted quality effect sensitivity model yielded similar results (RR 1.03; 95\%Cl 0.84-1.28).

Conclusion: Although, Ibuprofen and paracetamol appear to have similar tolerance and safety profiles in terms of incidence of asthma exacerbations in children, we suggest high quality trials with clear definition of asthma outcomes after receiving ibuprofen or paracetamol at varying doses with longer follow-up are warranted for any conclusive finding.
\end{abstract}

Keywords: Paracetamol, Acetaminophen, Ibuprofen, Wheezing, Asthma, Meta-analysis

* Correspondence: Lthalib@qu.edu.qa

${ }^{3}$ Department of Public Health, College of Health Sciences, QU Health, Qatar University, Doha, Qatar

Full list of author information is available at the end of the article

C C The Author(s). 2020 Open Access This article is licensed under a Creative Commons Attribution 4.0 International License, which permits use, sharing, adaptation, distribution and reproduction in any medium or format, as long as you give appropriate credit to the original author(s) and the source, provide a link to the Creative Commons licence, and indicate if changes were made. The images or other third party material in this article are included in the article's Creative Commons licence, unless indicated otherwise in a credit line to the material. If material is not included in the article's Creative Commons licence and your intended use is not permitted by statutory regulation or exceeds the permitted use, you will need to obtain permission directly from the copyright holder. To view a copy of this licence, visit http://creativecommons.org/licenses/by/4.0/ The Creative Commons Public Domain Dedication waiver (http://creativecommons.org/publicdomain/zero/1.0/) applies to the data made available in this article, unless otherwise stated in a credit line to the data. 


\section{Background}

Paracetamol, also known as acetaminophen, is one of most commonly used over-the-counter medication to treat pain and fever. Paracetamol is perceived as a safe medication to control pain and fever in children, yet evidence from multiple epidemiological studies have shown a potential association between its use and asthma. Epidemiological studies have found an increased risk across difference populations as well as a dose-response relationship [1-8]. A meta-analysis found the odds of wheezing doubles (OR 1.97; 95\%CI 1.51-2.56) in children exposed to paracetamol [9]. On the other hand, a recent study by Walsh and Rothenberg found a decreased in risk of wheezing in children when exposed to paracetamol for an episode of bronchiolitis or respiratory tract infection [10].

The increasing evidence accumulated over the past 30 years about the risk of asthma exacerbations associated with paracetamol has led clinicians to recommend a change in practice, particularly in children [11-13]. Among the alternatives to treat pain and fever in children, one that stands out is ibuprofen. A meta-analysis by Pierce and Voss found that ibuprofen is more effective in reducing pain and fever than paracetamol in paediatric population [14]. They also reported that ibuprofen and paracetamol had similar rates of adverse events; however, they did not assess the risk of asthma [14]. Ibuprofen as a nonsteroidal anti-inflammatory drug (NSAID), inhibits cyclooxygenase $(\mathrm{COX})$ and reduces prostaglandin synthesis. That in turn causes reduction in fever, inflammation, and pain. However, the inhibition of the COX pathway can also activate the lipoxygenase pathway, leading to an increase in leukotriene synthesis, and resulting in bronchospasms and asthma exacerbation [15].

The aim of this meta-analysis is to quantify the risk of wheezing and asthma exacerbations in paediatric population taking ibuprofen and paracetamol. Our findings are expected to help guide the paediatricians in management of fever and pain and drug choices.

\section{Methods}

Findings from this systematic review and meta-analysis are presented following the recommendations from the Preferred Reporting Items for Systematic Reviews and Meta-Analyses (PRISMA). The review was registered with the International Prospective Register of Systematic Reviews (CRD42017080165).

\section{Search strategy and study selection}

The search strategy was conducted in PubMed, Science Citation Index, Embase, Cochrane library, and ClinicalTrials.gov. The following search terms were included (paracetamol OR tylenol OR acetaminophen) AND ibuprofen AND (pediatrics OR children OR infants). All databases were searched from their inception until September
2017. The search was updated in July 2019 and was supplemented with a PubMed similarity search as well as a forwards and backwards citation search for the articles included in the meta-analysis. The references lists from relevant systematic reviews and meta-analyses were hand searched.

Eligible studies were RCTs conducted in humans that included paracetamol and ibuprofen within their study arms. To be considered for inclusion, the RCTs had to include children ( $\leq 12$ years) and reported the number of cases of wheezing, asthma and/or asthma exacerbations. The outcome of interest (i.e.wheezing, asthma or asthma exacerbation) could be reported either as the primary or secondary outcome or as an adverse event in the RCT. Studies were excluded if the study arms included co-interventions (e.g. paracetamol plus codeine). No language restriction was applied. Two authors (MS and JN) independently screened the articles. Disagreement was resolved through consensus.

\section{Data extraction and quality assessment}

A spreadsheet was used for data extraction. The following items were extracted by one of the authors (MS) author, year of publication, study setting and characteristics of the study population, follow-up time, characteristics of the interventions (e.g. dose of medication), sample size, and number of cases of wheezing or asthma excerbations. The extracted data was cross-checked by a second author (JD). The same two authors assessed the risk of bias of the RCTs using the Cochrane collaboration's tool for assessing the bias in randomized trials [16].

\section{Statistical analysis}

The effect measure of interest was the odds ratio (OR) of developing asthma exacerbations or wheezing after exposure to paracetamol compared to ibuprofen. The pooled OR was estimated using the Peto's method as the outcome was rare (three arms contained zero events). Statistical heterogeneity among studies was assessed using the $I^{2}$, an $I^{2}>50 \%$ was considered substantial between-study heterogeneity. Sensitivity analyses were conducted by excluding studies that measured exacerbation of asthma as their outcome as well as including the studies' quality information (i.e. risk of bias) into the model through the quality effects (QE) model [17]. Publication bias was investigated using the Doi plot and LFK index [18]. The analysis was conducted in MetaXL version 5.3 (EpiGear Int Pty Ltd.; Sunrise Beach; Australia; http://www.epigear.com).

\section{Results}

\section{Selection of studies}

The search identified 655 publications, 104 articles remained after title and abstract screening and the full text of the articles were examined to assess their 
eligibility. Eight publications met the inclusion criteria. Four publications $[8,19-21]$ used subsets of the Boston University Fever Study data, only the publication with larger sample size [19] was included in the metaanalysis. Therefore, five RCTs with 85,095 children were included in the meta-analysis (Fig. 1).

\section{Characteristics of included studies}

Four RCTs were conducted in hosptails [22-25], while one was conducted in paediatric and family medicine practices [19]. The age of the participants ranged from 2 months to 12 years with a mean age between 21 and 40 months. Four RCTs [19, 22, 23, 25] included only febrile children, their outcome of interest was episodes of asthma excerbations after the administration of paracetamol or ibuprofen, and had a relative short follow-up period ranging from $6 \mathrm{~h}$ to 28 days. Sheehan et al. [24] included afebrile children with asthma, thus the outcome of interest was exacerbation of asthma or wheezing after receiving paracetamol or ibuprofen, and had a longer follow-up period of 48 weeks (Table 1). Overall, the risk of bias was low among the RCTs, the most common deficiency was blinding of outcome assessment, followed by allocation concealment and blinding of participants and personnel (Table 2).

\section{Quantitative analysis}

The point estimates of two RCTs indicated lower risk of asthma exacerbations with paracetamol [22, 25], two RCTs point estimates indicated no difference [19, 24], while the last RCT point estimate favoured the use of ibuprofen [23]. Moderate statistical heterogeneity $\left(I^{2}=\right.$ $36 \%)$ among the five RCTs was observed. The pooled estimate (OR 1.05; 95\%CI $0.76-1.46)$ revealed that there is no difference in the odds of developing asthma exacerbations or wheezing in children who received paracetamol compared to ibuprofen (Fig. 2). When the analysis was restricted to RCTs that examined the episodes of asthma or exacerbations of asthma as their outcome of interest, the pooled estimate did not change (OR 1.01; 95\%CI 0.63-1.64). The QE model using the additional information from the quality assessment of each studies yielded similar results (RR 1.03; 95\%CI 0.84-1.28). The Doi plot and the LFK index $(-2.14)$ indicated major asymmetry in favour of RCTs reporting less episodes of asthma exacerbations with paracetamol compared to ibuprofen (Fig. 3).

\section{Discussion}

Although efficacy, safety, and tolerability of ibuprofen and paracetamol in children have been investigated [14, 26]; only few studies have investigated the association between asthma and the use of these medications. After a comprehensive search, only five relevant RCTs were identified and included in this review, which points out to the paucity of data in this area of research. The pooled estimate indicates that there is no statistical nor clinically important differences between the use of ibuprofen or paracetamol in the paediatric population in relation to asthma morbidity.

These null findings appear to be similar even among very young children. Lesko and Mitchell used a subset of their original data and compared the safety profile of these medications in children less than 2 years [21]. They found that the risk of hospital admissions due to asthma/

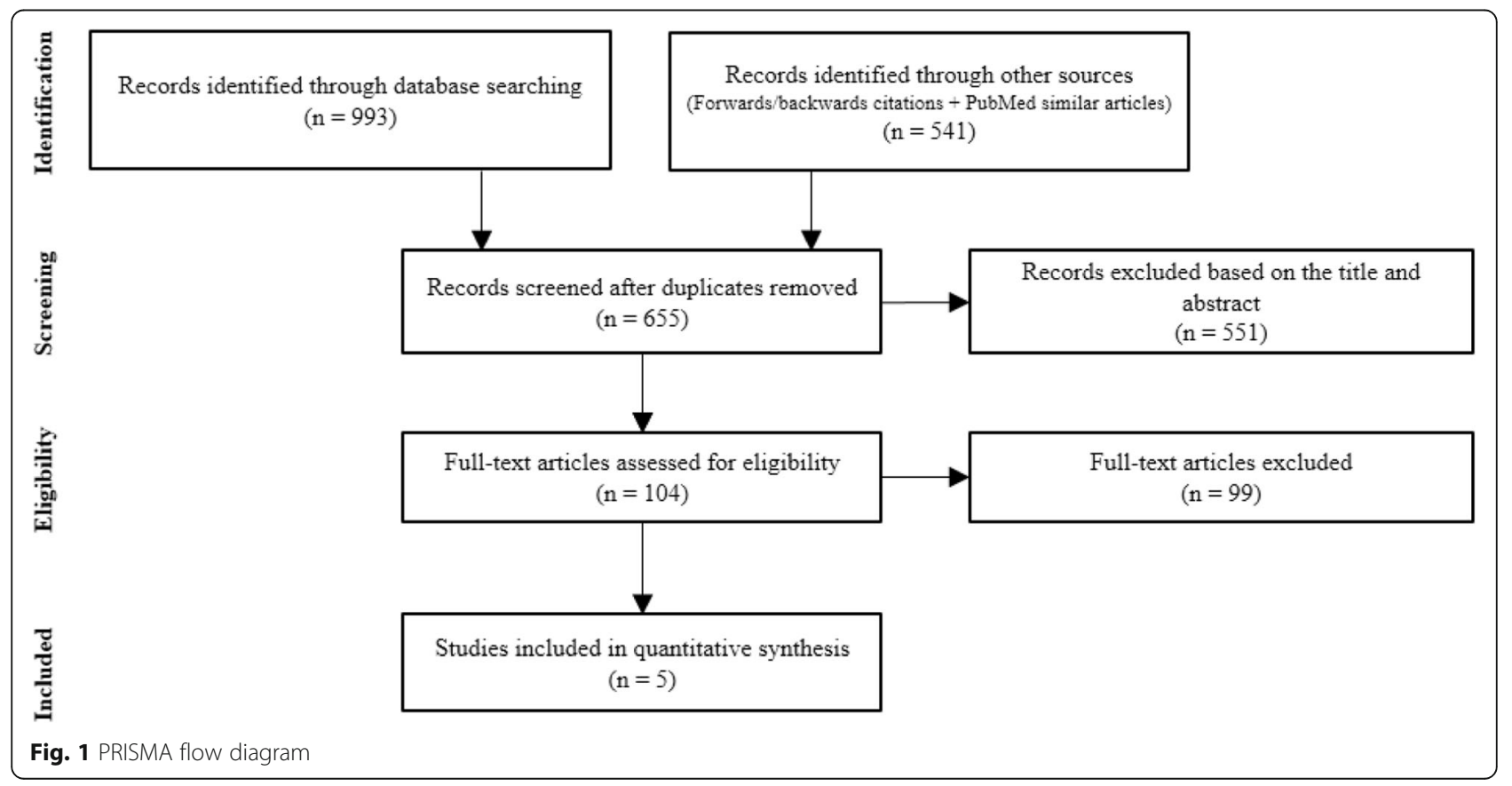


Table 1 Characteristics of the included randomised controlled trials

\begin{tabular}{|c|c|c|c|c|c|c|c|c|}
\hline Author, year & Setting & Study population & $\begin{array}{l}\text { Proportion of } \\
\text { females (\%) }\end{array}$ & $\begin{array}{l}\text { Mean/median } \\
\text { age (months) }\end{array}$ & $\begin{array}{l}\text { Follow-up } \\
\text { duration (days) }\end{array}$ & $\begin{array}{l}\text { Dose of } \\
\text { paracetamol/ } \\
\text { ibuprofen }\end{array}$ & $\begin{array}{l}\text { Number of } \\
\text { participants } \\
\text { paracetamol/ } \\
\text { ibuprofen }\end{array}$ & $\begin{array}{l}\text { Cases of asthma } \\
\text { paracetamol/ } \\
\text { ibuprofen }\end{array}$ \\
\hline $\begin{array}{l}\text { Lesko et al. } \\
1995 \text { [19] }\end{array}$ & $\begin{array}{l}\text { Outpatient } \\
\text { paediatric and } \\
\text { family medicine } \\
\text { practice } \\
\text { throughout } \\
\text { the US (1991-1993) }\end{array}$ & $\begin{array}{l}\text { Children aged } 6 \\
\text { months to } 12 \text { years } \\
\text { with acute febrile } \\
\text { illness } \\
\text { (Boston University } \\
\text { Fever Study) }\end{array}$ & 48 & 40 & 28 & $\begin{array}{l}12 \mathrm{mg} / \mathrm{kg} / \\
5-10 \mathrm{mg} / \mathrm{kg}\end{array}$ & $\begin{array}{l}28,130 / 55 \\
739\end{array}$ & $24 / 44$ \\
\hline $\begin{array}{l}\text { Luo et al. } \\
2017 \text { [22] }\end{array}$ & $\begin{array}{l}\text { Tertiary hospital } \\
\text { in China (2013-2014) }\end{array}$ & $\begin{array}{l}\text { Febrile children } \\
\text { aged } 6 \text { months to } \\
5 \text { years attending } \\
\text { the emergency } \\
\text { room }\end{array}$ & 40 & 30 & 5 & $\begin{array}{l}10 \mathrm{mg} / \mathrm{kg} / \\
10 \mathrm{mg} / \mathrm{kg}\end{array}$ & $158 / 157$ & $0 / 2$ \\
\hline $\begin{array}{l}\text { McIntyre } \\
\text { and Hull } \\
1996 \text { [23] }\end{array}$ & $\begin{array}{l}\text { Tertiary hospital } \\
\text { in the UK }\end{array}$ & $\begin{array}{l}\text { Febrile children } \\
\text { aged } 2 \text { months to } \\
12 \text { years }\end{array}$ & 41 & 21 & 3 & $\begin{array}{l}50 \mathrm{mg} / \mathrm{kg} / \\
20 \mathrm{mg} / \mathrm{kg}\end{array}$ & $74 / 76$ & $2 / 0$ \\
\hline $\begin{array}{l}\text { Sheehan et al. } \\
2016[24]\end{array}$ & $\begin{array}{l}18 \text { hospitals in the } \\
\text { US (2013-2015) }\end{array}$ & $\begin{array}{l}\text { Children aged } 1 \text { to } \\
6 \text { years receiving } \\
\text { long-term step } 2 \\
\text { asthma-controller } \\
\text { therapy } \\
\text { (The Acetaminophen } \\
\text { versus Ibuprofen in } \\
\text { Children with Asthma } \\
\text { trial) }\end{array}$ & 40 & 40 & 336 & $\begin{array}{l}15 \mathrm{mg} / \mathrm{kg} / \\
9.4 \mathrm{mg} / \mathrm{kg}\end{array}$ & $150 / 150$ & $74 / 70^{a}$ \\
\hline $\begin{array}{l}\text { Wong et al. } \\
2001[25]\end{array}$ & $\begin{array}{l}\text { University hospitals in } \\
\text { Argentina, Mexico, } \\
\text { Chile, and Brazil (1998) }\end{array}$ & $\begin{array}{l}\text { Febrile children aged } \\
6 \text { months to } 6 \text { years }\end{array}$ & 46 & 30 & 0.25 & $\begin{array}{l}12 \mathrm{mg} / \mathrm{kg} / \\
5-10 \mathrm{mg} / \mathrm{kg}\end{array}$ & $210 / 209$ & $0 / 2$ \\
\hline
\end{tabular}

${ }^{a}$ Cases of asthma exacerbations

bronchiolitis was similar with ibuprofen and paracetamol. Such a negative findings support the theory that risk of asthma morbidity is similar with ibuprofen and paracetamol. Their study also showed that the effect is not modified by the age. This is particular pertinent as the sample size in their study $(n=27,065)$ was large with sufficient power to detect even a small differences, if existed between drugs.

Potential biological mechanisms that underpin the role of these drugs in asthma exacerbations have been postulated.
Paracetamol is related to impaired lung function and asthma through a number of possible mechanisms; first being through oxidative stress. As paracetamol can lead to reduction of antioxidant glutathione concentration in the lungs, that can increase the oxidative stress in asthmatic patients. Bronchospasm through leukotriene release can be triggered by reactive oxygen species, which can greatly affect sensitive asthmatic patients $[27,28]$. A second mechanism is related to the lack of COX-2 inhibition by paracetamol which can trigger immune mediated response

Table 2 Assessment of risk of bias of the included randomised controlled trials

\begin{tabular}{|c|c|c|c|c|c|c|c|c|}
\hline Author, year & $\begin{array}{l}\text { Random } \\
\text { sequence } \\
\text { generation }\end{array}$ & $\begin{array}{l}\text { Allocation } \\
\text { concealment }\end{array}$ & $\begin{array}{l}\text { Blinding of } \\
\text { participants } \\
\text { and personnel }\end{array}$ & $\begin{array}{l}\text { Blinding } \\
\text { of outcome } \\
\text { assessment }\end{array}$ & $\begin{array}{l}\text { Incomplete } \\
\text { outcome data }\end{array}$ & $\begin{array}{l}\text { Selective } \\
\text { reporting }\end{array}$ & $\begin{array}{l}\text { Exposure } \\
\text { assessment }^{\text {a }}\end{array}$ & $\begin{array}{l}\text { Outcome } \\
\text { assessment }^{2}\end{array}$ \\
\hline $\begin{array}{l}\text { Lesko et al. } \\
1995 \text { [19] }\end{array}$ & Low risk & Low risk & Low risk & Low risk & Low risk & Low risk & High risk & High risk \\
\hline $\begin{array}{l}\text { Luo et al. } \\
2017 \text { [22] }\end{array}$ & Low risk & Low risk & High risk & High risk & Low risk & Low risk & Low risk & Low risk \\
\hline $\begin{array}{l}\text { Mclntyre and Hull } \\
1996 \text { [23] }\end{array}$ & Low risk & High risk & High risk & High risk & Low risk & Low risk & Low risk & Low risk \\
\hline $\begin{array}{l}\text { Sheehan et al. } \\
2016 \text { [24] }\end{array}$ & Low risk & Low risk & Low risk & Low risk & High risk & Low risk & Unclear & Low risk \\
\hline $\begin{array}{l}\text { Wong et al. } \\
2001 \text { [25] }\end{array}$ & Low risk & High risk & Low risk & High risk & Low risk & Low risk & Low risk & Low risk \\
\hline
\end{tabular}

${ }^{a}$ Exposure and outcome assessment were considered low risk if the information was obtained from medical records or directly recorded by the investigators, and high risk if it was self-reported by the parents or guardians of the children

The other items of the risk of bias were classified as low or high risk following the Cochrane collaboration's tool for assessing the bias in randomized trials [16] 


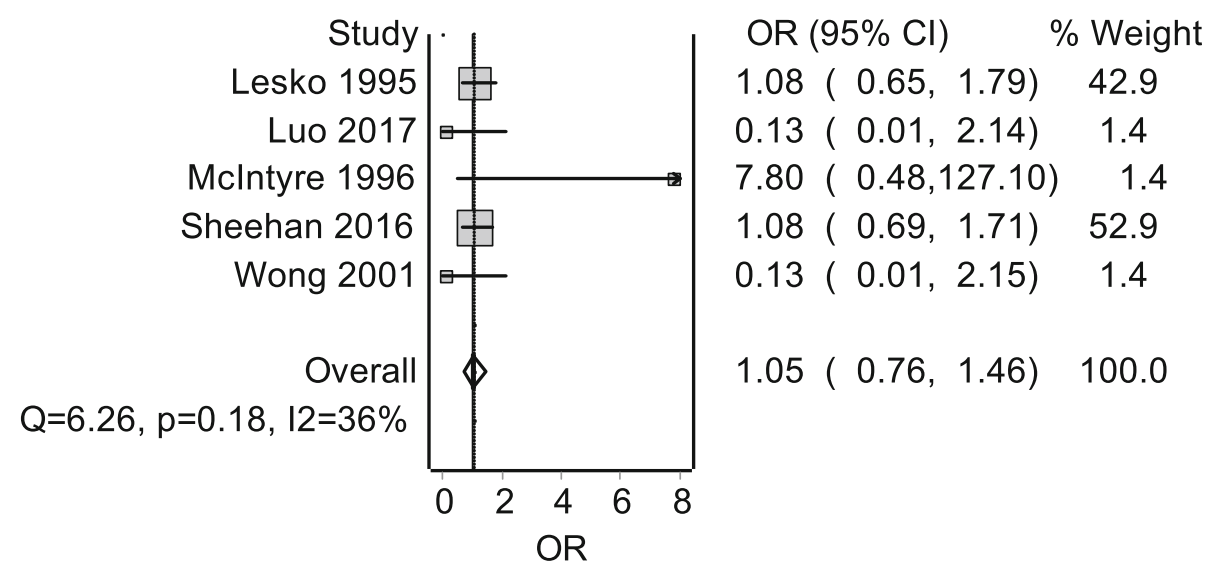

Fig. 2 Forest plot of the Peto's odds ratio of asthma in children who received paracetamol compared to ibuprofen

through $\mathrm{T}$ helper cells which increase sensitivity to an allergic tendency to different stimuli. Another study suggested that the frequent use of paracetamol can result in consistent decrease in intracellular glutathione levels which can be linked to asthma morbidity $[29,30]$. On the other hand, ibuprofen were thought to induce asthma symptoms through COX-1 enzyme blockage which increases thromboxane production and decreases production of

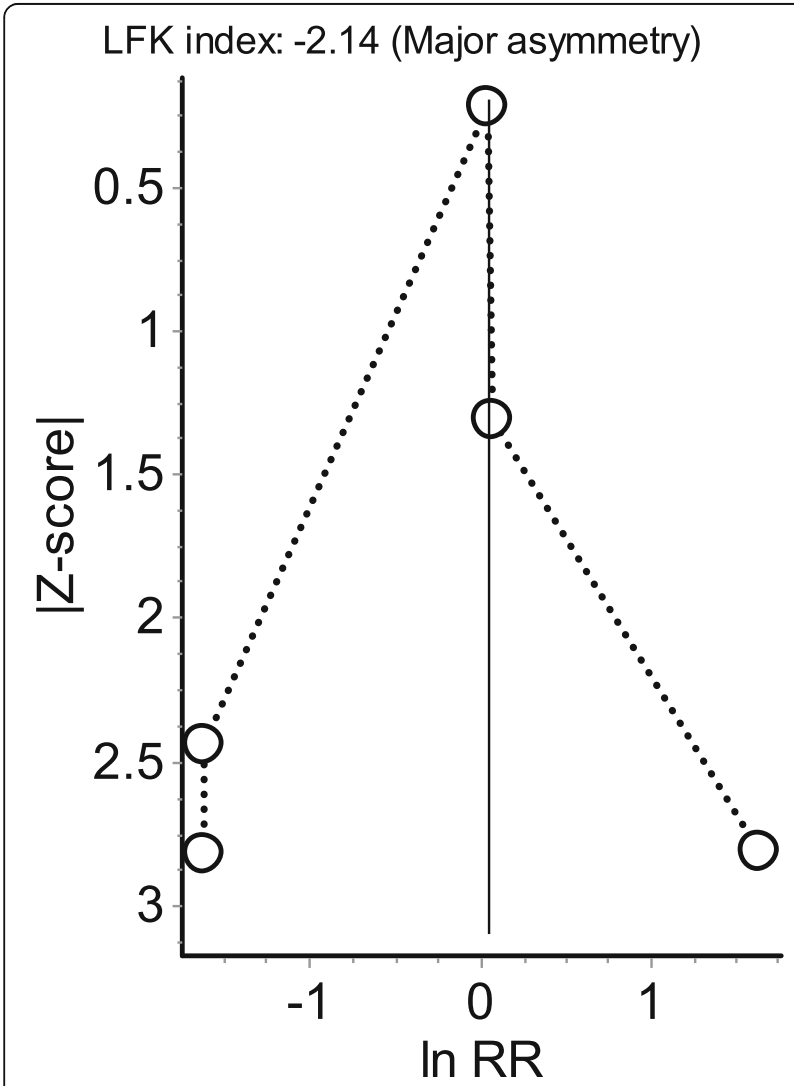

Fig. 3 Doi plot and LFK index for the detection of publication bias prostaglandins that have anti-inflammatory effect, leading to an increased release of pro-inflammatory leukotrienes which are chemical triggers for severe asthma exacerbations and allergy-like symptoms [31]. Although, the plausible biological pathways for paracetamol and ibuprofen to produce bronchospasms are different, findings from our study revealed that the net effect in bronchospasms is similar between both medications.

Our findings should be understood in the light of a number of limitations. The follow-up duration in four out of the five RCTs included in the meta-analysis was $\leq 28$ days. The association between medication exposure and diagnosis of asthma may require a longer follow-up period as symptoms could develop after 4 weeks. A large RCT, PIPPA Tamariki (https://pippatamariki.ac.nz) with a proposed follow-up of 6 year will provide more evidence about the risk of developing asthma in children exposed paracetamol compared to children exposed to ibuprofen within their first year of life. Asthma was not the primary or secondary outcome and was reported as an adverse event in four RCTs. The severity of morbidity from asthma was not consistent across all studies as one RCT included "mild wheezing" [23], while another used asthma exacerbation that required systemic glucocorticoids as the outcome of interest [24]. There were also variation in the dose of the interventions between RCTs as well as in the follow up time that ranged from $6 \mathrm{~h}$ to 48 weeks.

\section{Conclusions}

Our finding of similar tolerance and safety profiles of paracetamol and ibuprofen in terms of incidence or exacerbation of asthma in children is based on five RCTs. As there were paucity of research in this area, high quality trials with clear definition of asthma outcomes after receiving ibuprofen or paracetamol at varying doses with longer follow-up are warranted. 


\section{Abbreviations}

Cl: Confidence interval; COX: Cyclooxygenase; IVhet: Inverse variance heterogeneity; LFK: Luis Furuya-Kanamori; NSAID: Nonsteroidal antiinflammatory drug; OR: Odds ratio; PRISMA: Preferred Reporting Items for Systematic Reviews and Meta-Analyses.; QE: Quality effects; RCT: Randomised control trial; RR: Relative risk

\section{Acknowledgements}

None declared.

\section{Authors' contributions}

MS and LT conceived the idea and designed the study. MS, LFK and JD led the collection and assembly of the data. LFK and MS analyzed the data. MS LFK and LT interpreted the findings. MS and LFK drafted the manuscript and LT critically reviewed the manuscript. All authors have approved the final submission of the manuscript.

\section{Funding}

The publication of this article was funded by the Qatar National Library. The funding body had no role in study design, data collection, data analysis, data interpretation or writing of the manuscript.

\section{Availability of data and materials}

Data sharing not applicable to this article as the data used in the current study was extracted from published studies.

\section{Ethics approval and consent to participate} Not applicable.

\section{Consent for publication}

Not applicable.

\section{Competing interests}

The authors declare that they have no competing interests.

\section{Author details}

${ }^{1}$ Hamad Medical Corporation, Doha, Qatar. ${ }^{2}$ Research School of Population Health, Australian National University, Acton, ACT, Australia. ${ }^{3}$ Department of Public Health, College of Health Sciences, QU Health, Qatar University, Doha, Qatar.

Received: 2 October 2019 Accepted: 28 February 2020

Published online: 23 March 2020

\section{References}

1. Beasley R, et al. Association between paracetamol use in infancy and childhood, and risk of asthma, rhinoconjunctivitis, and eczema in children aged 6-7 years: analysis from Phase Three of the ISAAC programme. Lancet (London, England). 2008;372:1039-48. https://doi.org/10.1016/s01406736(08)61445-2.

2. Beasley RW, et al. Acetaminophen use and risk of asthma, rhinoconjunctivitis, and eczema in adolescents: international study of asthma and allergies in childhood phase three. Am J Respir Crit Care Med. 2011;183:171-8. https://doi.org/10.1164/rccm.201005-07570C.

3. McKeever TM, et al. The association of acetaminophen, aspirin, and ibuprofen with respiratory disease and lung function. Am J Respir Crit Care Med. 2005;171:966-71. https://doi.org/10.1164/rccm.200409-12690C.

4. Shaheen $\mathrm{S}$, et al. The relation between paracetamol use and asthma: a GA2LEN European case-control study. Eur Respir J. 2008;32:1231-6. https:// doi.org/10.1183/09031936.00039208.

5. Shaheen SO, Sterne JAC, Songhurst CE, Burney PGJ. Frequent paracetamol use and asthma in adults. Thorax. 2000;55:266-70. https://doi.org/10.1136/thorax.55.4.266.

6. Barr RG, et al. Prospective study of acetaminophen use and newly diagnosed asthma among women. Am J Respir Crit Care Med. 2004;169:836-41.

7. Amberbir A, et al. The role of acetaminophen and geohelminth infection on the incidence of wheeze and eczema: a longitudinal birth-cohort study. Am J Respir Crit Care Med. 2011;183:165-70. https://doi.org/10.1164/rccm. 201006-09890C

8. Lesko SM, Louik C, Vezina RM, Mitchell AA. Asthma morbidity after the short-term use of ibuprofen in children. Pediatrics. 2002;109:E20. https://doi. org/10.1542/peds.109.2.e20.
9. Etminan $\mathrm{M}$, et al. Acetaminophen use and the risk of asthma in children and adults: a systematic review and metaanalysis. Chest. 2009;136:1316-23. https://doi.org/10.1378/chest.09-0865.

10. Walsh P, Rothenberg SJ. Wheezing after the use of acetaminophen and or ibuprofen for first episode of bronchiolitis or respiratory tract infection. PLoS One. 2018;13:e0203770. https://doi.org/10.1371/journal.pone.0203770.

11. Allmers H, Skudlik C, John SM. Acetaminophen use: a risk for asthma? Curr Allergy Asthma Rep. 2009;9:164-7. https:/doi.org/10.1007/s11882-009-0024-3.

12. Johnson CC, Ownby DR. Have the efforts to prevent aspirin-related Reye's syndrome fuelled an increase in asthma? Clin Exp Allergy. 2011:41:296-8. https://doi.org/10.1111/j.1365-2222.2010.03683.x.

13. McBride JT. The association of acetaminophen and asthma prevalence and severity. Pediatrics. 2011;128:1181-5. https://doi.org/10.1542/peds.2011-1106.

14. Pierce CA, Voss B. Efficacy and safety of ibuprofen and acetaminophen in children and adults: a meta-analysis and qualitative review. Ann Pharmacother. 2010;44:489-506. https://doi.org/10.1345/aph.1M332.

15. Szczeklik A. The cyclooxygenase theory of aspirin-induced asthma. Eur Respir J. 1990;3:588-93.

16. Higgins JPT, et al. The Cochrane Collaboration's tool for assessing risk of bias in randomised trials. BMJ. 2011;343:d5928. https://doi.org/10.1136/bmj.d5928.

17. Doi SAR, Barendregt JJ, Khan S, Thalib L, Williams GM. Advances in the meta-analysis of heterogeneous clinical trials II: the quality effects model. Contemp Clin Trials. 2015;45:123-9. https://doi.org/10.1016/j.cct.2015.05.010.

18. Furuya-Kanamori L, Barendregt JJ, Doi SAR. A new improved graphical and quantitative method for detecting bias in meta-analysis. Int J Evid Based Healthc. 2018:16:195-203. https://doi.org/10.1097/xeb.0000000000000141.

19. Lesko SM, Mitchell AA. An assessment of the safety of pediatric ibuprofen. A practitioner-based randomized clinical trial. JAMA. 1995;273:929-33.

20. Lesko SM, Mitchell AA. Renal function after short-term ibuprofen use in infants and children. Pediatrics. 1997;100:954-7. https://doi.org/10.1542/ peds.100.6.954

21. Lesko SM, Mitchell AA. The safety of acetaminophen and ibuprofen among children younger than two years old. Pediatrics. 1999;104:e39. https://doi. org/10.1542/peds.104.4.e39.

22. Luo $\mathrm{S}$, et al. Alternating acetaminophen and ibuprofen versus Monotherapies in improvements of distress and reducing refractory fever in febrile children: a randomized controlled trial. Paediatr Drugs. 2017;19:479_ 86. https://doi.org/10.1007/s40272-017-0237-1.

23. Mclntyre J, Hull D. Comparing efficacy and tolerability of ibuprofen and paracetamol in fever. Arch Dis Child. 1996;74:164-7. https://doi.org/10.1136/ adc.74.2.164.

24. Sheehan WJ, et al. Acetaminophen versus ibuprofen in young children with mild persistent asthma. N Engl J Med. 2016;375:619-30. https://doi.org/10. 1056/NEJMoa1515990

25. Wong A, et al. Antipyretic effects of dipyrone versus ibuprofen versus acetaminophen in children: results of a multinational, randomized, modified double-blind study. Clin Pediatr. 2001;40:313-24. https://doi.org/10.1177/ 000992280104000602

26. Southey ER, Soares-Weiser K, Kleijnen J. Systematic review and meta-analysis of the clinical safety and tolerability of ibuprofen compared with paracetamol in paediatric pain and fever. Curr Med Res Opin. 2009;25:2207_ 22. https://doi.org/10.1185/03007990903116255.

27. Nuttall S, Khan J, Thorpe G, Langford N, Kendall M. The impact of therapeutic doses of paracetamol on serum total antioxidant capacity. J Clin Pharm Ther. 2003:28:289-94.

28. Dworski R. Oxidant stress in asthma. Thorax. 2000;55:S51-3.

29. Eneli I, Sadri K, Camargo C Jr, Barr RG. Acetaminophen and the risk of asthma: the epidemiologic and pathophysiologic evidence. Chest. 2005;127: 604-12. https://doi.org/10.1378/chest.127.2.604.

30. Dimova S, Hoet PH, Dinsdale D, Nemery B. Acetaminophen decreases intracellular glutathione levels and modulates cytokine production in human alveolar macrophages and type II pneumocytes in vitro. Int J Biochem Cell Biol. 2005;37:1727-37. https://doi.org/10.1016/j.biocel.2005.03.005.

31. Levy S, Volans $G$. The use of analgesics in patients with asthma. Drug Saf. 2001:24:829-41.

\section{Publisher's Note}

Springer Nature remains neutral with regard to jurisdictional claims in published maps and institutional affiliations. 